\title{
Recent Trends in Arbitration in Civil and Commercial Articles in Qatar within a Contemporary Legal Vision
}

Dr. Azab Alaziz Alhashemi

Professional International Arbitrator at Dispute Resolution Board Foundation, "DRBF"

DOI: $10.36347 /$ sjet.2020.v08i06.003

| Received: 12.06 .2020 | Accepted: 20.06.2020 | Published: 30.06 .2020

*Corresponding author: Dr. Azab Alaziz Alhashemi

\section{Abstract}

Original Research Article

The promulgation of the Arbitration law (No.2) of 2017, as the first independent and special arbitration law, is one of the most important complementary to the investment climate for the development and harmonization of national legislation and the universality of the environment for business and investment, ensuring the attraction and encouragement of foreign investment, and attracting prestigious international and global arbitration centers. In order to benefit from the arbitration law and to open branches in Qatar. Despite the positive, modern and innovative creation of the new country arbitration law, it contains a shortage. This has led the parties of arbitration to unsolved legal positions and has prolonged the dispute and that will be briefly addressed.

Keywords: Arbitration - Civil and Commercial Articles - Qatar - Future Outlook.

Copyright @ 2020: This is an open-access article distributed under the terms of the Creative Commons Attribution license which permits unrestricted use, distribution, and reproduction in any medium for non-commercial use (NonCommercial, or CC-BY-NC) provided the original author and source are credited.

\section{INTRODUCTION}

The judiciary is the principal means of resolving disputes, but as the conditions of trade and domestic and international investment have evolved, other means of dispute resolution have been urgently needed, in keeping with this global trade development and arbitration as an alternative means of dispute resolution has been older than the judiciary. The old concept of arbitration was more conciliatory than a means of dispute resolution, but arbitration had evolved as international trade and the global investment movement evolved [1].

Most of laws of the world have even given it a section in its laws governing arbitration, and some of them to enact arbitration laws, which represent arbitral proceedings and the composition of the arbitral tribunal, which has approached many judicial procedures and formations. International conventions and treaties have protected and guaranteed the enforcement of arbitration provisions.

International arbitration was no longer an alternative means of resolving international trade disputes. But it had become the primary means of resolving such disputes, and, unfortunately, it had begun to take many of the judicial disadvantages of prolonging the conflict and problems and difficulties of implementation.
This development and international interest in arbitration, As an alternative means of resolving disputes and problems in which other means of dispute resolution have begun to emerge, especially since arbitration in the United States has not known the progress that Europe has achieved during that period, unlike Europe, where the judiciary volunteered to take the hands of arbitration and to give it alternative means of resolving disputes. This reduces the burden on the judiciary and remains under its control after the judgment was issued.

\section{THE RESEARCH IMPORTANCE}

Indeed, the flourishing, expanding and increasing horizons of arbitration in the area of administrative law have been accompanied by the growth of internal and international economic relations among individuals. As the state's descent into the fields of trade has led to the growing internal and international economic relations between States and its desire for economic development. The general needs of society were satisfied with the emergence of inter-State relations, interests and national or foreign law, which had led to acceptance of the idea of arbitration in administrative disputes. The legislature entrusted the Administrative Court. 
In the light of recent amendments to the Administrative Court of Justice to consider matters relating to administrative contracts, to apply in respect of such disputes the provisions of the Civil Commercial Arbitration law. So that the Court became competent to hear the invalidity claim and to appoint the arbitrator. The preparation of the evidence, preventive action, as well as consideration of the problems of implementation.

\section{THE RESEARCH METHODOLOGY}

The research adopted the comparative analytical methodological approach.

\section{THE RESEARCH AIMS}

Despite the positive, modern and innovative development of the new country arbitration law, it contains legal observations that lead the parties of arbitration to unsolved legal situations and to the prolongation of the dispute, we will briefly address them: [2].

The draft in article (1), paragraph (8), of the Arbitration law provided the definition of the competent court as:

"The Civil and Commercial Arbitration disputes Chamber of the Court of Appeal, or the Primary Chamber of the Civil and Commercial Court of the Center of Qatar for money, on the agreement of the Parties."

The Qatari legislature also authorized the definition of multilateral arbitration (the original pluralization of the parties of arbitration) in the text of paragraph (5) of the same article, to the extent that the parties of the dispute themselves were two or more parties or of the dispute, that is (Two or more sides).

Article (33) of the same law provided that the competent court had jurisdiction in considering an action to invalidity the arbitral award.

The foregoing is that the Qatari legislature gave the option to the arbitrators in choosing the court competent to hear an action that invalidity the arbitral award.

Either bring the claim of invalidity before the Court of Appeal's Civil and Commercial Arbitration dispute Chamber, or before an international court, the Civil and Commercial Court of the QFC. At first glance, this provision appears to be an advantage, but in fact it is a legal gap and an obstacle to the arbitrators, leading to the prolongation of the dispute. Thus, the aim of the arbitrators to resort to arbitration, namely, the speed of adjudication of the dispute, has not been reached.

\section{THE RESEARCH PROBLEM}

In keeping with this qualitative shift and the comprehensive progress witnessed by the State of institutions and the law, the Omani legislator did not overlook the importance of developing the Qatari arbitration system in addition to the development witnessed by the judiciary.

It gives arbitration the utmost importance, as the other legislations, in support of foreign investments, and giving investors guarantees that would make them feel safe and secure in employing their capital in the authority, as many legislated and regulated country decrees penalize the arbitration and the competent authorities.

In order to realize the need to keep pace with the development of the international arbitration system, as well as the speed and flexibility required by other transactions, the legislature passed the Civil and Commercial Arbitration law by the Qatari decree, but arbitration was not limited to commercial and civil disputes only.

It has even been extended to administrative disputes to which the State or a subject of public law is a party as a public authority, and which were never envisaged to resort to arbitration to resolve such disputes[3].

\section{THE RESEARCH PLAN}

First requirement: Non-judicial means of dispute resolution.

Second requirement: The Qatari Arbitration law in Civil and Commercial Articles.

Third requirement: Business standard in the Qatari arbitration law.

\section{First requirement}

Arbitration as a special judicial system

Recourse to arbitration as a means of dispute resolution is an important procedure, consisting in the departure from the ordinary methods of litigation in the State and the disqualify of the jurisdiction of the State party, since the jurisdiction of the arbitral tribunal should be limited to the consideration of the subject matter of the dispute to which the arbitrators' will is vested. The court must not necessarily be subjected to it.

Otherwise the arbitration clause would require the courts not to accept the claim and the tendency to introduce the arbitration system; as an alternative to recourse to the courts to resolve disputes between the parties to the contractual relationship, which may be motivated by the speed of adjudication of arbitral disputes; Moreover, when the parties of the dispute agree to keep this disagreement secret and not to 
publish it, the important reference in the introduction of the arbitration system is the desire of the parties of the dispute to be decided by arbitrators with a degree of technical specialization that cannot be achieved in the jurisdiction of the State with the public jurisdiction.

Arbitration in banking and commercial transactions, international construction contracts, international sale of goods, maritime and other disputes; Most of them require that the arbitrator have professional specializations that the State cannot know except by bringing them to the experts - which entails prolonging their adjudication, despite the importance of ending disputes fast in the near future - and achieves for his parties a realistic judiciary according to the technical concept of the conflict subject, which entails the safety of this The judiciary.

Also, resorting arbitration would be the agreement of the disagreement parties to select people who had confidence of each of them, the judgment on the subject of the dispute would be a provision made only within a family Council; This excludes hatred between the parties of disagreement in the dispute, love and intimacy spread among them despite a ward issued for one of them before the other.

The desire of traders and entrepreneurs to keep others not informed of their differences is also realized, and resorting to arbitration is the effective means of not publishing their differences in public, even in respect of arbitration proceedings and the judgments that may be issued. This is the case where most legislation has been made that arbitration provisions may not be published or portions thereof published except with the consent of the parties to arbitration, since the arbitration proceedings are attended only by the parties and their lawyers[4].

\section{Definition of arbitration}

On the basis of the foregoing, arbitration may be defined as: "Agreement to bring the dispute to a designated person or persons for adjudication without resorting to the competent court".

Under such arbitration, adversaries waive resorting to the courts, committing themselves to submit the dispute to one or more arbitrators to adjudicate by binding judgment of the adversaries, possibly depending on a particular contract in which the process is mentioned and called (arbitration condition), and may be on the occasion of a particular dispute that already exists between the adversaries and is called in this case (Arbitration or arbitration agreement).

If States permit arbitration, it is for the purpose of facilitating for adversaries and until a substantive body is adjudicated in the dispute to avoid court hearings and proceedings, while in any case saving time and effort, and arbitration is based on two grounds:
A- The will of the opponents.

B- And the legislator's approval of this will.

By agreeing to arbitration, the arbitrator shall be empowered to adjudicate the dispute rather than the court competent to consider it, for the court's will to conclude the arbitration shall be limited to replacing the arbitrator in the consideration of the dispute, so that if the arbitration contract is not executed for any reason, the power of judgment shall be returned to the court.

There is a link between arbitration and judicial assets, either to start a contract and end a judgment, or to be subject to the rules of civil law in terms of its convening, and in this case, to be subject to the law of proceedings, in terms of effects, enforcement and procedures, arbitration shall invalidate the invalidating of contracts, and its judgment shall be challenged. Judgments are also challenged and implemented and sentences are enforced.

The legal regulation of arbitration is based on the consent and acceptance of the parties as a means of resolving all or some of the disputes that have been or may arise between them on the occasion of a particular legal relationship, whether contractual or not, and the will of the contractors creates and defines the scope of arbitration in terms of matters covered by it and applicable law.

The composition and powers of the arbitral tribunal, arbitration proceedings, etc. Thus, once the agreement had been left behind, he had refrained from stating that arbitration had taken place, which would have a comparative effect and would only be invoked to confront the party which had accepted it and before its opponents.

\section{Aspect of binding in arbitration}

We have seen from the foregoing that in arbitration the arbitrator replaces the Court, and the power to commit it is transferred to him.

If the opponent fails to appear before the courts after being assigned to appear correctly, or if they fail to make a defense, the court cannot prevent the judge from ruling in his trial, and the sentence is enforceable against them, as is the court ruling.

If the legislator requires the execution of the arbitrator's judgment to be ordered, it is merely to verify and control the work of the arbitrator; it derives its powers only by agreement of the adversaries on arbitration [5].

The control of the mere verification that the arbitrator has taken into account the form required by the law is considered to be the only one to be able to verify that Whether in the adjudication of the dispute or 
in writing of its judgment, without prejudice to the subject of the dispute, the judge, when the execution order is issued, shall clarify the executive wording of the judgment of the arbitrator, so that the judgment of the matter is not left to the Registry.

The arbitration condition does not authorize the arbitral tribunal to take any action before a dispute occurs, but the requirement will begin to be enforced if the dispute actually occurs.

On the basis of this definition, it can be said that the provision consists of two elements:

One is for the parties to the conflict, and the other is for the judicial activity of the arbitrators, which is as following:

1- Agreement by interested parties to resort to arbitrators in the event of a dispute to be determined by mutual agreement.

2- Judicial activity by the arbitrators, which ends with the normal result, is the issuance of a judgment.

This definition resonates with many scholars in many Arab or foreign countries, which are based on these two elements: The element of agreement and the element of judicial activity, which is performed by the arbitrators of the majority of jurists, shall demonstrate their will to submit to arbitration and its simplified procedures for what will be done later upon the signing of the arbitration agreement, whatever form this agreement takes.

\section{Difference between arbitration and experience}

It is necessary to differentiate between the arbitrator and the expert, since the initiator is that they are in a single sense. But arbitration is different from experience. The arbitrator serves as a judge and the dispute between the adversaries is resolved and his opinion is imposed on them, while the expert is a person who may be an assistant to the arbitrator or judge.

If there is no dispute, he may be an agent of those parties to such assistance or the agency, not the purpose of resolving a particular dispute, but rather a specialized opinion on a problem; since the expert gives an opinion, this view has no binding force, either for the judge, the arbitrator or the parties requesting that view.

In this respect, the arbitrator is different from the expert. The former is a judge of the adversaries who are entrusted to him by agreement with certain powers. The latter is intended to resolve a particular dispute. They entrust him with judicial function or commit themselves as a general principle to the decision reached within the limits of this task and in view of the same subject matter [6].
Therefore, the expert may ask the adversaries to submit specific documents to help him to take his opinion, contrary to the arbitrator who is not entitled to do so, but to award the documents submitted to him and under his authority[7].

However, doubts often arise with regard to certain conventions in which adversaries are referred to persons who are engaged in the task of resolving the dispute on a particular subject, and who are entrusted with the task of determining the amount of debt resulting from the resolution of the dispute, and a dispute has been raised in jurisprudence and the judiciary in determining the nature of the agreement.

Some argued that it was a mere contract of private law and could not be considered arbitration in the right sense, and another view was that it was a wise agreement in the right sense, and indeed that the view on grounds that deserved support took into account the type of task entrusted to the expert arbitrator.

The view that this agreement is considered a preliminary endorsement is that the reason why this view is so strong is that the expert arbitrator, in order to arrive at the assessment of the amount of compensation or the value of the right, must, under his judicial function, settle the dispute first.

If he succeeds, he becomes involved in this matter. The arbitration shall then, on the basis of the experience gained, assess the amount of compensation or the right in general and therefore the arbitration shall be based on it.

Thus, it is true that this agreement is described as arbitration as the correct description of such an agreement, unless another thing is understood of the contract between the parties, and this does not change the fact that this assignment, unless it is carried out in a document similar to the arbitration agreement, and it's not considered arbitration.

In all conditions the Convention cannot be considered an arbitral provision which would be laid down in the executive form of its implementation.

\section{Difference between arbitration and reconciliation}

The arbitration and conciliation systems are distinct. In the reconciliation, the conflicting parties have made a mutual waiver, each of whom has waived some of their rights in exchange for something similar to the other, in order to resolve the dispute that may exist between them.

In fact, in the legal system of the reconciliation, the parties to the dispute are separated from their orders, but in arbitration the parties are present as adversaries in a case in which their proceedings are before the arbitrator, who is another person. 
On the other hand, in reconciliation, we find mutual concession from each side for part of its rights. In arbitration, one party may win the whole case. As persons in a dispute are going to one or more nondisputing persons to find a solution to their dispute and the solution to which such interests may be accepted by such persons.

Therefore, it is appropriate to serve as a basis for the subsequent conciliation and resort to the conciliation. Where in fact it is carried out without compliance with any procedural or substantive rules. Although this is illegal for this type of social solution, it is nevertheless considered a system that is limited in the legal field.

Nor are these persons doing the reconciliation considered to be judges or arbitrators of the reconciliation for the obvious reason. The decision or solution they reach has no binding force for persons who resort to this method. So, what the conciliators do should be a proposal for direct reconciliation among the adversaries.

The reconciliation is considered illegal for social solution and it's limited to legal field. In addition, that, the conciliators are not considered judges in jurisdiction or judges in reconciliation. That's for an obvious reason that, their decisions and solutions are not binding for the parties of the dispute.

The contribution in this reconciliation is, therefore, merely an event of moral value to the opponents of the expected reform procedure by a reconciliation document adopted by the parties to the antagonism.

Noting that the judgment of reconciliation cannot express his opinion of the dispute before the judgment of reconciliation is issued, Contrary to the conciliator who expresses his point of view to the parties of the conflict before they have written the report of the reconciliation [8].

\section{Second requirement \\ The Qatari Arbitration Law in Civil and Commercial Articles}

Article (1):

In applying the provisions of this Law, the following words and phrases have the meanings indicated in their text, Unless the context gives another:

\begin{tabular}{|c|l|}
\hline Minister & Minister of Justice \\
\hline Ministry & Ministry of Justice \\
\hline Arbitration & $\begin{array}{l}\text { a legal method of agreement to resolve the dispute rather than resort to the judiciary, whether or not } \\
\text { the party to the arbitration procedures under the agreement of the parties has a permanent status of } \\
\text { arbitration. }\end{array}$ \\
\hline $\begin{array}{c}\text { Arbitration } \\
\text { Agreement }\end{array}$ & Article (7), Agreement (Item1) of this law. \\
\hline Parties & party or parties to the dispute who have agreed to refer it to arbitration. \\
\hline $\begin{array}{c}\text { The arbitral } \\
\text { tribunal }\end{array}$ & $\begin{array}{l}\text { the tribunal composed of an individual arbitrator or a number of arbitrators, to decide on the } \\
\text { dispute referred to as arbitration. }\end{array}$ \\
\hline $\begin{array}{c}\text { The other } \\
\text { authority }\end{array}$ & $\begin{array}{l}\text { The authority chosen by the parties to their agreement, as permitted by this law, to perform certain } \\
\text { functions relating to assistance and supervision of arbitration, whether it is a permanent arbitration } \\
\text { center or institution. }\end{array}$ \\
\hline $\begin{array}{c}\text { The competent } \\
\text { court }\end{array}$ & $\begin{array}{l}\text { the Civil and Commercial Arbitration disputes Chamber of the Court of Appeal or the Trial } \\
\text { Chamber of the Civil and Commercial Court of the Center of Qatar for money on the basis of the } \\
\text { agreement of the parties. }\end{array}$ \\
\hline $\begin{array}{c}\text { The competent } \\
\text { Judge }\end{array}$ & $\begin{array}{l}\text { first instance execution Judge; Or the enforcement judge of the Civil and Commercial Court of the } \\
\text { Qatari Financial Center if the parties agreed. }\end{array}$ \\
\hline The Prosecutor & the party to the agreement that initiates a request for the dispute to be referred to arbitration. \\
\hline The defendant & a party to the agreement against which the dispute is referred to arbitration. \\
\hline $\begin{array}{c}\text { Arbitration } \\
\text { Centers }\end{array}$ & \begin{tabular}{l} 
each legal entity authorized to conduct arbitration in accordance with the provisions of this Law. \\
\hline
\end{tabular} \\
\hline
\end{tabular}

Article (1) of this law, defining the other authority, noting that the Qatari legislature has developed a new philosophy of jurisdiction over arbitral proceedings by creating another authority instead of the court, which is used to shorten arbitral proceedings and which appoints arbitrators whose appointment has failed to be appointed by the parties.
The appointment of the Chairman of the arbitral tribunal if the arbitrators fail to agree on his choice, and even more[9] so, has given it the power to judge the appeal of the arbitrators and even to judge appeals against the arbitral tribunal's decision in its jurisdiction or any other defenses decided by the tribunal, This is favoured to strengthen the principle of willpower of the parties to arbitration, if they do not wish to resort to justice at any stage of the arbitration. 
Article (2): The scope of this Law...

1- Without neglecting the provisions of international conventions in force in a country, the provisions of this law shall apply to any arbitration between parties of public or private law, whatever the nature of the legal relationship in question, if such arbitration is taking place in the State or if it is an international arbitration taking place abroad, The parties agreed to submit it to the provisions of the law.

2- The agreement on arbitration in administrative contract disputes shall be with the approval of the Prime Minister or his authorized delegate, and in no case shall public law persons resort to arbitration to resolve disputes arising between them.

3- In applying the provisions of this law, arbitration shall be commercial if a dispute arises over a legal relationship of an economic nature, contractual or non-contractual, including commercial, investment, financial, banking, industrial, insurance, tourism or other economic nature.

What kind of arbitration contract has been defined by the preceding article?

Arbitration may be concluded before the dispute by a contract item established by the parties, in which the agreement usually states: "If a dispute occurs in the interpretation of the contract, execution or effects of the contract, it shall be referred to arbitration".

This is called the "arbitration condition" in most Arab laws. The "arbitration document" in the Saudi arbitration system and Egyptian law, or the "arbitration agreement" in the Qatari and Kuwaiti law, the name of which was chosen by the Arabic-Egyptian language Academy.

Arbitration may take place after the dispute has occurred, and the conflicting parties then conclude an agreement to resort to arbitration, which is called the "arbitration conditioning".

In both cases, the arbitration was concluded on the satisfaction of the parties. It is a contract of law and law that is an optional contract to be replaced by dispute and rivalry, and whose purpose is to set it off to reach a fair solution[10].

The State as a party to the arbitration agreement...

If the State is a party of the arbitration agreement, the question arises as to the extent of the conflict between the arbitration agreement and the sovereignty of the State, the view is that the State in the arbitration area enjoys its sovereign prerogatives, in terms of its only submission to its law, inadmissibility of arbitration in its administrative contracts and inadmissibility of the enforcement of the arbitration award against the State.
However, international arbitration provisions have been made in another doctrine, where a set of applicable legal principles has been developed when the State is a party to the arbitration agreement, including:

1- The law is applicable to legal entities emanating from the State, which is the national law under which these legal entities have been established, and the legal personality of a ministry can only be reasonably determined in accordance with the law of the State to which the Ministry is responsible.

2- A State cannot apply its national law if that would justify its refusal to abide by an arbitration agreement it has concluded.

3- When the Government or State has entered into an arbitration agreement, it waives its sovereign immunity concerning this agreement.

4- The State is not a party to an arbitration agreement concluded by one of its organs, since the personality of the State is separated from the public personality of the person arising from it.

5- A State may not rely on non-recognition by the international community to evade its undertaking of an arbitration agreement.

The Qatari Arbitration Law limited the agreement on arbitration to administrative contracts to the approval of the Council of Ministers.

The following paragraph of the second paragraph of article II prohibited persons from resorting to arbitration.

Thus, it is understood from this article that the Qatari legislator excluded only the Council of Ministers or those authorized only to sign a condition Arbitration participant.

The ambiguity of the situation of the legislator in determining the role of the will of the adversaries in the choice of rules applicable to arbitral proceedings in article (2)

Article (2), paragraph (1), of the Qatari Arbitration Law states that:

"Without neglecting the provisions of international agreements used in the State, the provisions of this law shall apply to any arbitration between parties of public or private law, whatever the nature of the legal relationship in question, if such arbitration is taking place in the State, or it was an international commercial arbitration conducted abroad and its parties agreed to subject it to the provisions of this law.

This article addresses the statement of the law applicable to arbitral proceedings, and in so doing it has been made between two hypotheticals: 
Qatar.

First: If arbitration takes place in the State of

Second: If arbitration is commercial internationally and is conducted abroad [11].

\section{First: If arbitration takes place in the State of Qatar}

Article (2) of the Arbitration law states that the provisions of this law that apply to arbitral proceedings, if they are conducted in the State regardless of the parties, whether they are figures of a public law or a private law, whatever the nature of the legal relationship arising from the dispute before it, whether commercial or civil, is contractual or not.

This article determined that the Qatari Arbitration law No.2 in 2017, which applies to arbitration proceedings in Qatar obligatory, regardless to the will of the adversaries, did not give the adversaries the right to choose the law applicable to such proceedings, as long as arbitration takes place in the State, The Quatri arbitration law applied to its procedures, and the legislator considered the rules of the law to be such an instant application.

However, article (19) of the Arbitration Law has brought a provision which may appear to be contrary to the provision in article (2) referred to, as stated in article (19):

"Parties agree on arbitration proceedings, including the rules of evidence to be signed by the arbitral tribunal, it shall have the right to subject such proceedings to the rules in force in any organization or arbitration center in or outside the State", as stated in the second paragraph. The arbitral tribunal may apply the proceedings it applies appropriate procedures.

The legislator has given the parties to arbitration the right to determine the law applicable to their proceedings, which entitles them to exclude the application of the Qatari arbitration law and to choose another law, to apply to arbitration proceedings.

This means that, according to article (19), mentioned before, the law applicable to arbitration in Qatar in respect of the proceedings is subject to the will of the parties, contrary to article (2) of the Arbitration law, to apply its procedural provisions to arbitration in Qatar; without taking into account that will.

But does that mean that there is a contradiction between the text of articles (2) and (19) of the Arbitration Law?

We believe that there is no conflict between the text of these articles, each has a different scope of application.

When the legislator mentioned article (1) ruled that the arbitration law should apply to arbitration in Qatar, the procedural rules concerning public order were intended in this law, which apply to arbitration in
Qatar without requiring agreement on the parties' will to apply them.

The rules aimed at ensuring the ensuring the arbitration dispute, which are based on two fundamental principles, are no different from any procedural law or any agreement on it in the law and the judgment of the course of the dispute.

Thus, it may be argued that article (2) has a different scope of application than article (19) of the Arbitration Law, and article (2) applies to arbitral proceedings, irrespective of the will of the adversaries and the law they have chosen. With regard to the procedural rules on public order, which are contained in the Qatari arbitration law and apply article (19) on other procedural rules[12].

The applicability of public order provisions of the Arbitration Law to any arbitration in Qatar is necessary and important and is relevant in the implementation of the arbitration provision.

If this provision is made in contravention of a rule relating to public order in Qatar, it will be refused to implement it because of this violation, pursuant to the provision of the Qatari Arbitration Law, which states: "The award may be ordered to be executed in accordance with this law only after verification that it does not include any violation of the public order of the State".

Although there is no conflict between the provision of articles (2) and (19) of the Qatari Arbitration Law in the light of the interpretation we have already set before, However, it remains that the existence of these articles in their current legislative wording may lead to confusion and may be a cause for doctrinal disagreement.

We therefore propose that, in order to prevent confusion and to avoid doctrinal disagreement, these articles be combined into one article, which reads as follows:

1- without neglecting the provisions of the international conventions in force in the State of Qatar and the general rules of procedure in this Law, the parties to the arbitration shall agree on the procedures followed by the arbitral tribunal, including their right to subject such proceedings to the rules in force in any organization or arbitration center within or outside the State; If this agreement does not exist, the arbitral tribunal may choose the appropriate arbitration proceedings.

2- the preceding paragraph shall apply to each arbitration between parties to the public or private law. Whatever the nature of the legal relationship that is involved in the dispute, whether it is being held in Qatar or abroad. 
Second: If arbitration is conducted outside the State Article (2) of the Qatari Arbitration Law requires the provisions of this Law to apply to international commercial arbitration conducted outside Qatar if the parties agree, since the legislator has openly recognized the role of the parties will determine the law applicable to arbitration outside the State.

The application of the provisions of the Qatari Arbitration Law to such arbitration shall be required by the parties to agree to apply it, but the freedom of the parties to exclude national law and to choose a foreign law applicable to arbitration proceedings in such case, restricted by respect for and rules of procedure relating to public order in the Qatari Arbitration Law.

The arbitration award will be carried out in Qatar in accordance with the above-mentioned law and the clarification we have already mentioned.

However, when the legislator in article (2) mentioned the internal arbitration within the State, he merely stated arbitration "without describing it, the legislator did not qualify it as commercial or civil, when he spoke in the same article about arbitration taking place outside the country, he said, "International commercial arbitration [13]".

The legislator may be confused; he may think that the dispute is international only if it is commercial, whereas the international character of arbitration is not related to its commercial description. Arbitration shall be international in accordance with certain criteria defined in article (2) of paragraph (4) of the Arbitration Law, not including the criterion of the commercial character of the dispute, and international civil arbitration may be said not to be subject to arbitration law, whereas this law shall apply to arbitration whatever the legal nature of the dispute in question is, Whether a commercial dispute or a civil dispute, in accordance with the text of article (2) itself, is the object of such criticism, and to avoid confusion, the legislator should have used in article (2) of the Arbitration Law the terms "internal arbitration"; "International arbitration" without description so that it includes arbitration in both civil and commercial disputes alike.

\section{Third requirement}

Commercial business standard in the Qatari arbitration law

Article (2) paragraph (3) of the Arbitration law provides that: "Arbitration shall be commercial in the provision of this law, if the dispute arises over a legal relationship of an economic nature, contractual or noncontractual, including commercial, investment or financial transactions, Banking, insurance, industrial, tourism or other transactions of an economic nature".
The legislator has adopted a vacuum standard in this text. To determine what is a commercial act, and that is the economic nature of the legal relationship, where it was stated at the beginning of the article that, arbitration would be commercial in the provision of this law if the dispute arose over a legal relationship of an economic nature.

The legislator had indicated "in the rule of this law", To make it clear that the business criterion of an economic nature is related to an arbitration law standard, and deviates from the standard established by any other articles of the law.

After the legislator in the Arbitration law has established the criterion of the economic nature of employment to be a commercial act, He didn't present this standard only, although presented a series of examples of commercial businesses whose arbitration for the consideration of disputes arising from it is a commercial arbitration.

The conduct of the legislator in this paragraph of article (2) of the mentioned Arbitration law has been the subject of many criticisms and questions. Most of the criticisms were centered on the deletion of the word "commercial" from the text of this paragraph of the article (2) referred to, as well as the deletion of all the examples in it, and the only criterion for the economic nature of the dispute for the possibility of arbitration. Any dispute arising out of a legal relationship of an economic nature may be presented to arbitration.

One suggestion we see is that there is no need for a word commercially, as it will make us limited to commercial materials only, while there are many examples in the same article that are not commercial in nature.

These many examples can be shortened and broadly expressed, so that we can amend this article as follows:

"Arbitration shall be subject to the provisions of this Act if the dispute arises over a legal relationship of an economic nature, whether contractual or not. Whether it is civil, commercial, credit, industrial or agricultural".

\section{Article 2 paragraph (4)}

Arbitration shall be international, in the application of the provisions of this Law, if the object of which is a dispute relating to international trade, This is the following:

If the main status of the work of each of the parties to the arbitration agreement at the time of the conclusion of the agreement is in different States. And if a party has more than one place of business, choosing the place of business that is the most relevant at the 
subject of the arbitration agreement and if a party to the arbitration agreement hasn't a place of business, the place is his habitual residence.

A- If the principal status of business of all parties to the arbitration agreement is in the same country at the time of the arbitration agreement, and one of the following places is outside that state:

- The place of arbitration as defined by the arbitration agreement or mentioned on it how it is determined.

- The place where a substantial part of the obligations arising from the relationship of the parties is implemented.

- The most relevant place to the dispute.

B- If the subject matter of the dispute covered by the arbitration agreement concerns with more than one country.

C- If the parties agree to resort to a permanent arbitration institution based inside or outside the state.

Distinction between national and international commercial arbitration

\section{First: Geographical basis}

The first criterion for differentiation adopted by some State laws is that arbitration is considered foreign if one of the parties is foreign. Arbitration shall be internal if the two adversaries belong to the nationality of the State under arbitration, and another criterion used by the New York Convention on Arbitration is that arbitration shall be foreign if the arbitral award is adjudged in a State other than the State requesting the enforcement of the arbitration award on its territory.

The Geneva Convention on International Arbitration of 1961 has adopted another criterion; The dispute arises from an international commercial operation if the dispute between persons residing in different countries or with permanent residence centers in them.

The United Nations Convention on International Commercial Arbitration (UNCITRAL) of 1985 has taken another basis that arbitration is considered international if at the time of the conclusion of the arbitration agreement, the adversaries are residing in different States.

\section{Second: Economic basis}

Some of the jurisprudence has taken on another basis that the dispute concerning international commercial interests is the basis for international arbitration without regard to the place of arbitration or the nationality of the adversaries. French Arbitration law of 1981 has taken this criterion.

Therefore, According to this consideration, if there is a project to establish an oil refinery in a particular State by national companies, but based on international contracts to import all project equipment from a foreign State or States, this dispute is the basis for international arbitration, Because of the international interests involved in the implementation of the project, even if its parties were national and were implemented on the territory of the same State[14].

The importance of the distinction between national and international arbitration:

1- If the arbitration is internal, it's possible for the national jurisdiction to control the arbitration award by dealing with the subject of the dispute, which is applicable in some States, While the laws of some States do not allow national jurisdiction to deal with the subject of the dispute when requesting the implementation of the international arbitration award.

2- The international arbitration is broader than internal arbitration. National law may not permit arbitration in labor disputes, while international arbitration permits it and there some national laws prohibit the State and public bodies from presenting their disputes with individuals and companies to internal arbitration, but they may resort to international arbitration in their disputes with foreign companies, and the laws of the State apply to internal arbitration. Thus, the arbitration provision that controverts the national arbitration law is considered null. Considering that arbitration is a means of achieving justice. Thus, it affects public discipline, while national arbitration law does not apply to international arbitration. National courts examine the arbitration provision in terms of its compatibility with public discipline. Global jurisprudence and justice had led to the fact that the search was intended to be the extent to which the international arbitration award was compatible with international public order and not with internal public order.

3- National laws have drawn attention to the importance of the distinction between internal and international arbitration, to limit the, interference of national courts with international arbitration, as such a distinction leads to attracting international arbitration to States whose laws are not obstructing it and which do not uptie it to the rules of internal arbitration. Because the international arbitration has not a concern with the state economy or with its legal discipline. In order to that The internal and the international arbitration laws were issued separately in France with a difference of one year, the first was issued in 1980, the second was issued in 1981, as well as do the English legislator and the Lebanese legislature in 1983.The Belgian legislature has adopted a very advanced approach to international arbitration law, stating that the Belgian judge is not competent to invalidate the international arbitration award. 
4- Modern jurisprudence has tended to make the economic standard more likely than geographic one, and arbitration is considered international under the following conditions:

First: Its subject is commercial to operations with an economic object.

Second: That such trade should be international, with a movement of funds, goods or services across the geographical boundaries of States.

5- The Model Law of The United States for Arbitration of 1985 provides in articles $(1 \& 3)$ that arbitration is considered international in the following cases: First: If business place of the parties of the arbitration are located at the time of its conclusion in different States.

Second: If the place of arbitration located in a State other than the place of business of the parties.

Third: The implementation of the principal obligations arising from the commercial contract is different from the parties' place of business.

Fourth: If the parties expressly agree that the subject matter of the arbitration agreement relates to more than one State[15].

First: The idea of national public discipline

1- Public Policy order: It's a package of orders in the laws of a State that cannot be violated, and the combination of political, economic, social and moral systems that underpin society. The last one is considered one basis of public discipline, even if it is not provided in the laws, and does not provide for the inadmissibility of its violation. That's because it is considered to be the pillars of society and agreed upon for hundreds of years.

2- The idea of public order is flexible and varies according to place and time. Thus, which is considered to be a public order in a State, may not be considered as such in another State, but may be considered an offense. And what is considered a public order in a particular era in a particular State may not be considered as such in another era in the same State.

An example of difference in place: The call for the establishment of a monarchy in a republic is considered a crime, because the republican system is a rule of public order, and vice versa.

An example for the difference of the rules of public order in time: Cigarette smoking in some Arab countries was considered to be contrary to the public order of public morals. It is now permissible and does not violate public order.

3- The rule of the world is that any agreement or conduct contrary to the general order of the State is totally null and void. Therefore, the judiciary has the power to invalidate it on its own without seeking from the adversaries of the case, and the invalidity is not corrected with permission. The contract or conduct is liable to be paid with absolute invalidity, and therefore the arbitration award issued in contravention of public order is liable to be invalidity, once submitted to the national court for execution, and may be challenged on invalidity with an independent basis for its violation of public order.

Second: The idea of international public order

1- In view of the conflicting notion of public order among States, the idea of international public order has emerged for the international trade relations involving parties of different nationalities, whose disputes are considered before international arbitration.

Modern jurisprudence has tended to point out that in this area the protection of the public interests is not concerned a particular society, but to take into account another matter which is the protection of international solidarity which requires the contribution of each State to the development of relations among peoples. To create a mutual understanding that creates peace. Since considering the international trade is the best way to communicate and exchange resources between peoples.

So, each State should facilitate such communication and eliminate obstacles to its realization, even if requiring some sacrifices to achieve that.

Therefore, the international solidarity requires an application for foreign law in the event of its compatibility with the interest of international trade, and if it doesn't harm the public interest of the State[16].

2- The idea of international public order could be conceived as it achieving the conciliation of the State interests into line with the international trade interests. Therefore, the judge would judge according to his/her persuasion. Because it is impossible to define accurately the national interest and the international interest. And the jurisprudence in France has settled that the arbitration ruling that contradicts the French public order can be executed in France even if the arbitration was considered in France.

Thus, if an arbitral award is adjudged in a labor dispute between an employer and a worker of both non-French workers, such arbitration is international and the French judiciary does not invalidate such a provision. Although French law does not allow arbitrating in labor disputes. and arbitration is considered in France, but it is not contrary to international public order. Although it is contrary to French internal public order.

3- The international commercial arbitration court has taken the idea of international public order, and provisions have been made to accept the dealing with gold in international contracts. Which provides protection against price fluctuations. In this regard, the judiciary has preferred to protect international trade rather than the national interest 
The laws of all States indicate the invalidity of the deal with gold to protect the national currency.

The provision of the law prohibiting the use of arbitration by government and public sector persons in disputes arising from contracts entered into by those bodies as it is related to internal public order and not to international public order.

Thus, it's ruled that government and public sector authorities could approve the arbitration clause in international contracts they entered into in a condition that such contracts belong to private law contracts rather than administrative contracts.

4- Applying the idea of international public order, The United States Supreme Court has ruled that, Trade with world markets and international seas cannot be exercised in accordance with our terms derived from our laws applied by the United States courts. Because the rules of national public order are not applied to international commercial disputes.

The US judiciary has ruled with the execution of an arbitration award adjudged in a dispute between a bankrupt US company and a Japanese company, although the US public order rules prohibit presenting bankruptcy proceedings to arbitration.

5- The question arises as to a clear concept of the rules of international public order, and to answer this question, it can be said to be the general principles established in the States of the world that abide by law and legality. Such as respecting human rights in general and respecting his right to physical, moral and artistic property.

Also the inadmissibility of the execution of the obligation in kind if it is against the debtor's person or liberty, non-discrimination on grounds of sex, race or religion, and some international arbitration provisions have ruled that the rules of international public order do not permit the claim to perform unlawful commissions before arbitration.

As in some cases, the arbitral tribunals responded to the substantive requests and rejected the Commission's application. This provision is established in (nemo auditur) principle. As it's not permitted for a person to benefit from a cheat he commits. There is an Islamic basis assure that Those who sought a wrong pursuit, its returns return to them.

6- Some jurisprudence has called for the improvement of the permanent attempt by arbitrators to create obstacles in the way of agreements in violation of the interests of the State which is adversely affected by commissions. As well as agreements against ethics in international economic relations.

Some doctrine has argued that the international arbitrator of the present era must has an objective thinking, responsive to different cultures as well as political and social systems. He should not be affected with main culture when he judges in a dispute. These considerations are also vital for the Chairman of the arbitral tribunal as likely to be heard when the arbitrators are different, but such considerations are also required in the members of the arbitral tribunal [17].

7- International agreements on international commercial arbitration have provided for respect for the rights of the defense. Such as The Geneva Convention of 1927, the New York Convention of 1958 and the European Convention of 1961. All of which provided for the repeal of any provisions of arbitration that would waste the rights of the defense, and that, those rights were not linked to a particular national law.

These are universal rules based on the need to treat opponents equally and also based on the principle of public action and pleadings. Thus, a breach of defense rights is a breach of international public order.

8- An example of the judicial tendency to distinguish between internal public order and international public order is a case which has been heard before the Tunisian judiciary.

It's brought by the Tunisian Electricity Company, a public sector company against the French company Entrepose, to adjudge in a dispute arising from a gas transport contract in Tunisia.

The French company argued that the Tunisian judiciary was not competent to deal with the dispute, on the basis of the arbitration clause of the International Chamber of Commerce provided for in the contract, which considers the dispute that may arise from the contract in Geneva. The Tunisian company also responded to this defense that Tunisian law prohibits government and public sector authorities from resorting to arbitration in their contract disputes.

The Tunisian court refused to claim its incompetence in the case, and the Tunisian company's defense refused. This is on the understanding that the prohibition provided for in Tunisian law is not applicable to international contracts.

9- Another example of the application of the idea of international public order is that the judgments of the American courts have long established that anti-monopoly cases cannot be heard by arbitration, provided that the US Supreme Court ruled in a recent judgment that this rule applies to internal disputes. However, such disputes may be adjudicated by arbitration if such disputes are international.

10- Some States have developed national and international arbitration laws. Such as the French International Arbitration law of 1981, and the domestic Arbitration law of 1980, as well as does Lebanon. The aim of this trend is to retain the national arbitration law, which may be based on a stable old tradition. A law on international arbitration is passed, so that the judiciary has a clear legislative instrument for the distinction between internal and international arbitration, rather than leaving it to the appreciation of the 
jurisprudence, which is the right solution for States that do not want to change national arbitration law. Thus, judicial interference with the international arbitration judgment is flexible and limited without the national judges being critical to the rules of national public order when considering the application for or challenging the application of international arbitration provisions.

11- One of the international arbitration provisions in this regard is the International Chamber of Commerce Arbitration Tribunal judgment of 1975, where the Commission concluded that:

The arbitrator is not forced to fully comply with the law, which the opponents agreed to apply to the dispute, but he always has the freedom to reject the solutions emanating from this law which is objected to the international public discipline. The arbitrator has the authority to reject what are established of the national legal provisions. Also, he shall not be entitled to form the law of the State in accordance with its own view, but establish it according to the public lawful rules [18]. In its interpretation of contracts, it depends on general legal principles and on the universally established spirit of common law.

12- This provision is strong enough to reflect the application of the idea of international public order. Under this consideration, the Governing Body rejected certain rules of law which the adversaries agreed to apply to the subject of the dispute, and this refusal established that these rules are contrary to the general spirit of law (Esprit Commun La Loi) which means the general principles of law recognized by civilized States. The provision has been made to reject the application of established jurisprudence to these principles, which has been rejected.

Thus, the provision highlights the special nature of international arbitration, namely that it is based on justice and not on the application of the legal norms applied by the formal judiciary. This is a special kind of justice (Sui Generis).

13- It is recognized, however, that the application of the notion of international public order in international arbitration disputes, even if it is not in breach of the rules of internal public order, should not result in damage to a national interest of great importance to the State.

So, the national jurisdiction when it is presented with an international arbitration award, it carefully balances the international public order with the internal public order and weights them according to what it sees. As there are no rules for the distinction between the international public order and the internal public order.

In addition, the judiciary has always been mindful of the relaxation of internal public order without prejudice to the national interests of the State to which it belongs and the aim of that is to facilitate international trade that is detrimental of the control of national interests on its own path.

\section{CONCLUSION}

Through the previous review of recent trends in arbitration in administrative contracts, we conclude with the following points:

1- Arbitration, which constitutes a quasi-judicial system, is the most successful and optimal means of resolving economic contractual or noncontractual disputes. Due to the speed of its procedures, the flexibility to adjudicate these disputes and the secrecy which are little to be found in the judicial system.

2- The Islamic law is the first that has laid the basic foundation for resorting to arbitration in transactions between people. It is an ancient discipline in civilizations, with the growing industrial revolution and the virtual world.

3- The emergence of arbitration in the field of administrative contracts in Qatar began in this age of blessed renaissance with the beginning of commercial development in the early 1980s.

Starting with the establishment of a committee, then the Commercial dispute resolution Authority. The system of litigation and arbitration applications was introduced after that. But the arbitrators at that time were public officials of the State administrative machinery and arbitration in administrative contracts constituted a landmark comparable to that of various States. It's in line with the Qatari openness in tourism, investment and commerce into the outer world. The country's arbitration law in civil and commercial disputes has been brought into line with the agreements and treaties signed by the State. In order to benefit cooperation with countries of the world.

This was reinforced by the recent amendments to the Administrative Court of Justice law No. (6 bis) added to the country decree, which stated that:

"the provisions of the Arbitration law in Civil and Commercial disputes shall apply to administrative deductions relating to administrative contracts. The arbitration matters referred to the law shall be heard by the courts in respect of administrative contracts of the Trial Chamber, the Appeals Chamber or the President of the Court, depending on the circumstances," in which the Trial Chambers shall have "first degree courts" in arbitration disputes the power to take action, reservations and time, and assistance in gathering and presenting evidence.

The Court shall also consider the problems of execution of the President of the Arbitration Court, while the Appeals Chamber shall have the power to hear the invalidity claim, and the President of the Court only have the authority to appoint the arbitrator or the arbitral tribunal.

4- Arbitration is an exceptional way of resolving disputes, based on the exit of ordinary litigation. 
The adversaries resort to it rather than judicial recourse, and they are obliged to present the dispute for one or more arbitrators. The contract is characterized as a "consensual contract", since the appointment of the court is only final and complete with the consent of the adversaries. As the principle that dominates this contract is the power of will and the freedom of contractors, as well as the closest to a "contract of compensation"; because the arbitrator performs work for the opponents, they perform the material equivalent of the arbitrator who deserves for the service he performs.

5- Arbitration as a dispute resolution system does not expropriate the jurisdiction of the judiciary, but only gives the parties of the legal and contractual relationship and other freedom to choose arbitration as a means of resolving their disputes arising from such relations. Where the judiciary retains its full jurisdiction and authority in the implementation of the arbitration agreement. It then controlled the validity of this Agreement, the validity of arbitration proceedings, the validity and implementation of the decisions of the arbitral tribunal and the validity of the decisions of the arbitral tribunal. In addition, it has an important role to play in the matter of supporting the arbitral tribunal in the discharge of its duties.

6- The jurisdiction of the Administrative Court in arbitration in administrative contracts extends to the department's activity for non-contractual liability that falls within the scope of the administrative decision review proceedings, and is not limited to contractual liability alone.

\section{THE RECOMMENDATIONS}

1- The interest in the arbitration system in the curricula, as there is an urgent need for outputs, recognizes the value and importance of arbitration activity in all legal acts.

2- The scientific reality in Qatar through prepared questionnaires proves that, the rumor that arbitration in administrative contracts has the speed to decide on the judgment is a matter of regulation. As the court of administrative justice in Qatar has the tools and abilities to settle this kind of case with a successful and fair speed during all stages of the judicial degree - most of all - for twelve months, and it exceeds the period that the arbitrator spends to settle such dispute.
3- special codification should be developed to resort to administrative arbitration in administrative contracts - especially with national companies Because of the high cost of arbitration and other reasons for which the parties resort to establish different contracts that are not applicable in such a way that the wide powers and privileges enjoyed by the administration in such contracts in particular are often undermined or impeded.

4- The study recommends the need to initiate the establishment of an independent arbitration center in some States to monitor arbitrators, receive complaints and other matters.

\section{REFERENCES}

1. Arbitration law in Egypt and Arab States, parts I and II.

2. International Commercial Arbitration, Lectures for students of the Law of the Cairo Law Faculty; 1974.

3. The Civil articles of Arbitration Law.

4. Optional and compulsory arbitration.

5. Arbitration within the framework of the Cairo Regional Center.

6. International Commercial Arbitration; 1999.

7. Maritime arbitration.

8. General basis for international commercial arbitration.

9. Contract.

10. The mediator in the Civil Law.

11. Arbitration in Arab laws.

12. Lectures in arbitration.

13. Arbitration provisions of the Cairo Center.

14. Regional Commercial International Arbitration parts $1: 6$.

15. Arbitration cases issued by the Arab Center for Arbitration.

16. Absolute Arbitration in the light of Islamic law.

17. International commercial arbitration (comparative legal study).

18. Arbitration law in theory and practice.

19. Lectures on the fundamental problems of international arbitration from a development perspective.

20. Cash judiciary in civilian articles.

21. Studies in arbitration law.

22. The arbitration origins of engineering disputes.

23. Multilateral arbitration. 